\title{
Assessment of Awareness, Knowledge and Related Behaviours Towards COVID-19: A Cross-Sectional Study of Clients and Health Care Workers in Obstetrics and Gynecology Clinics in Anyigba, North Central Nigeria
}

\author{
Simon Akogu, Rosemary Alexander-Onoja, Busayo Agbana, and Timothy Idachaba
}

\section{ABSTRACT}

Introduction: COVID-19 is a viral disease that was first seen in Wuhan China in December 2019. Nigeria had its first case of COVID 19 in February 2020.

Healthcare workers in obstetrics and gynecology clinics are front line health workers because while they are providing reproductive health services, they are prone to encountering persons with transmissible COVID19 disease.

Aim: The aim of this study is to assess awareness, knowledge and related behaviors of clients and Healthcare workers in obstetrics and Gynecology clinics towards COVID 19 and its preventive strategies.

Subjects and Methods: This is a descriptive cross-sectional study that was done among health workers in Obstetrics and Gynecology Clinics in four hospitals in Anyigba North Central Nigeria and the attendees of these clinics. The questionnaire sought to assess awareness, knowledge and related behaviors of clients and Healthcare workers in obstetrics and Gynecology clinics towards COVID 19 and its preventive strategies. Data was collected from the $1^{\text {st }}$ of July to the end of September 2020.

Results: One thousand and $48(1,048)$ respondents were studied. Majority of the respondents $52.3 \%$ knew of corona virus through television, followed by other media $(19.7 \%)$ and from health workers $(17.7 \%)$. Only $9.9 \%$ heard of corona virus through the radio. The mean percentage score for knowledge transmission and prevention of COVID-19 is $76.6 \%$ ranging between $58.9 \%$ and $90.2 \%$.

Conclusion: The respondents demonstrated high level of awareness, knowledge, and acceptable positive behavior towards the COVID-19 pandemic necessary to guarantee service modifications to prevent person to person transmission.

Submitted :May 31, 2021

Published:June ${ }^{* *}, 2021$

ISSN: $2593-8339$

DOI: $10.24018 /$ ejmed.2021.3.3.901

Simon Akogu *

Obstetrics and Gynecology Department, Kogi State University/Kogi State University Teaching Hospital, Anyigba, Nigeria.

(e-mail:Simon.a@ksu.edu.ng)

Rosemary Alexander-Onoja

Department of Public Health, Kogi State University/Kogi State University Teaching Hospital, Anyigba, Nigeria.

(e-mail: maryonoja41@gmail.com) BusayoAgbana

Department of Public Health, Kogi State University/Kogi State University Teaching Hospital, Anyigba, Nigeria. (e-mail: agbanabusayo ${ }^{@}$ yahoo.com) Timothy Idachaba

Nursing Services Division, Kogi State University Teaching Hospital, Anyigba, Nigeria.

(e-mail: timothyidachaba29@gmail.com)

*Corresponding Author

Keywords: COVID-19, Health Care Workers, Awareness, Knowledge, Anyigba, Nigeria.

\section{BACKGROUND}

The corona virus disease 2019 also called COVID-19 is a rapidly expanding viral disease that was first seen in Wuhan China in December 2019. It was subsequently characterized and named 2019 - nCov [1]-[3]. [0], [11].

It has since reached all the continents of the world and is posing serious challenges to health care and development [6][8], [12], [13], [19].

Nigeria had its first case of COVID-19 in February 2020. Since then, the cases continue to grow despite control measures put in place. While the world waited for the vaccines to halt the spread of the virus and the availability of the vaccines to everyone that needs them, the mainstay of prevention has been the non-pharmaceutical measures.

The world Health Organization (WHO) recommended prevention of the virus to ensure that both clients/patients and health care workers are protected from infection by this highly infectious virus [10], [14].

Healthcare workers in obstetrics and gynecology clinics are front line health workers because while they are providing reproductive health services, they are prone to encountering persons with transmissible COVID-19 disease. It is therefore important that they know about COVID-19 and its preventing strategies. Pregnant women who access ANC, Women who come into labour ward, postnatal clinic and other persons encountered in the other services in obstetrics and gynecology are capable of transmission of COVID-19 to 
health workers here and are also at risk of contracting it from the health workers [14], [16], [19].

Our study is assessing the awareness, knowledge, and related behavior towards COVID-19 among these health workers and their clients that visit them. The findings will enrich the body of knowledge and enhance our control measures.

\section{SubJECTS AND Methods}

This is a descriptive cross-sectional study that was done among health workers in Obstetrics and Gynecology Clinics in four hospitals in Anyigba North Central Nigeria and the attendees of these clinics. The clinics are located in Holley Memorial Hospital Ochadamu, Grimard Catholic Hospital, Neighbour Multicare Hospital and the Kogi State University Teaching Hospital all in the Anyigba axis of the Eastern Part of Kogi State, North Central Nigeria. Data was collected from the $1^{\text {st }}$ of July to the end of September 2020. A selfadministered structured questionnaire pretested in another clinic not involved in the study was used.

\section{A. Study Subjects}

All attendees of the clinics both male and females and the services providers in the clinics (Health care workers) were the participants in the study. A convenience sampling technique was used to select the participants. The Obstetrics and Gynecology Clinics within Anyigba environment have an estimated cumulative annual patient population of 95,000 (Ninety-five thousand) that access services.

At $95 \%$ confidence level and confidence interval of 5, we used the survey system sample size calculator to obtain a sample size of 761. This was further increased to 1250 to accommodate exclusions for incomplete response. Data collectors adhered to strict COVID-19 protocols.

\section{B. Study Tools}

A self-administered structured questionnaire pretested in another clinic not involved in the study was used. There were interpreters where the respondents did not understand the questionnaires written in English language that carried the same meanings as the questionnaires in English.

The questionnaire sort to obtain information on respondents' demographic characteristics, educational level, and their awareness and source of information about COVID19 and went further to assess their knowledge of transmission and prevention of COVID-19. The related behavior of the respondents with the advent of COVID-19 and their level of confidence that the national government will be able to contain a national outbreak was also assessed.

\section{Ethical Issues}

The Ethical committees and the managements of the institutions that housed the clinics where this study was carried out gave the relevant clearance and permissions. The respondents gave verbal consent before the administration of the questionnaire.

\section{Statistical Analysis}

All completed questionnaires were coded and entered intostatistical package for social sciences version using descriptive analysis that used numbers and percentages mainly.

\section{RESULTS}

Analysis of the imputed data revealed the following: one thousand and $48(1,048)$ respondents completed the questionnaire correctly. These were made up of health care workers $(45.1 \%)$ and non-health care workers $(54.4 \%)$ as in Table VI. $41.2 \%$ were males and $58.3 \%$ were females.

The mean age of the respondents is $33 \pm 5$ years with $50.4 \%$ in the age bracket below 30 years and $19.6 \%$ in the age bracket $31-40$ years.

$66.5 \%$ of the respondents have attained post-secondary school education; only $6.1 \%$ had no formal education.

As in Table I, $91.2 \%$ of the participants are aware of the corona virus disease while $76.2 \%$ believe that COVID-19 is in Nigeria.

Table II shows that majority of the respondents $52.3 \%$ knew of corona virus through television, followed by other media (19.7\%) and from health workers (17.7\%). Only $9.9 \%$ heard of corona virus through the radio.

The results of knowledge assessment of the participants for transmission and prevention of COVID-19 are shown in Table III. The mean percentage score for knowledge is $76.6 \%$ ranging between $58.9 \%$ and $90.2 \%$.

For all items assessed, more than $50 \%$ of the participants had correct answers for knowledge assessments irrespective of their background. The least correct answer was 58.9\% on the issue of asymptomatic carriers of the corona virus where the respondents were almost evenly distributed on whether people with COVID-19 "may not have any complain at all". However, majority agreed with this thus showing good knowledge. The mean percentage of wrong answers for knowledge assessment was $22.9 \%$ among the respondents ranging between 9.1 and 40.7 with the majority below $30 \%$. Wrong answers were higher on the issue of asymptomatic carriers of the virus $(40.7 \%)$. Whether corona virus disease is curable $(38 \%)$ and whether we can touch our eyes, mouth, and nose with unwashed hands (34\%). These were the areas where significant knowledge gap was observed.

Table IV shows the related behaviors of the participants towards the COVID-19 pandemic. While $80.9 \%$ said the pandemic has change the way they do things, $16.7 \%$ said it has not at all while $2.9 \%$ believed there are some changes.

With respect to daily activity, $40.9 \%$ believe the pandemic has changed their daily activities a lot while $23.2 \%$ did not think so. Another $34.5 \%$ believe there are some changes in their daily activities but not a lot.

$74.3 \%$ of the respondents have changed their plans a lot due to the pandemic, $19.1 \%$ did not change any plans at all but $6.2 \%$ did some changes but not a lot of it.

Majority of the respondents $(57.2 \%)$ are not very confident that the federal government of Nigeria can prevent large outbreak of (COVID-19). The majority (54.7\%) also are not very confident that they (themselves) are prepared for large outbreak of COVID-19 in Nigeria.

$30.7 \%$ of the health workers are not confident at all that the federal government of Nigeria can prevent large outbreak of COVID-19. Similarly, $26 \%$ of the non-health workers also are not confident at all that the federal government can prevent large outbreak of COVID-19 (Tables V\&VI). 
TABLE I: AWARENESS OF CORONA VIRUS BY RESPONDENTS

\begin{tabular}{cccc}
\hline & \multicolumn{3}{c}{ Score } \\
\hline Awareness & Yes & NO & Total \\
Have you heard of & $960(91.2)$ & $88(8.4)$ & $1048(100)$ \\
Corona Virus & & 246 & $1048(100)$ \\
$\begin{array}{c}\text { Corona Virus is in } \\
\text { Nigeria }\end{array}$ & $802(76.2)$ & $(23.4)$ & \\
\hline
\end{tabular}

TABLE II: HOW RESPONDENTS HEARD OF CORONA VIRUS

\begin{tabular}{ccc}
\hline Medium & $\mathrm{N}$ & $\%$ \\
\hline Radio & 104 & 9.9 \\
Television & 550 & 52.3 \\
Health Worker & 186 & 17.7 \\
Other Media & 208 & 19.7 \\
Total & 1048 & 100 \\
\hline
\end{tabular}

TABLE III: KNOWLEDGE OF CORONA VIRUS DISEASE TRANSMISSION AND

\begin{tabular}{|c|c|c|c|}
\hline Questions & $\begin{array}{c}\text { NTION BY RE } \\
\text { Correct } \\
\text { Answers N } \\
(\%) \\
\end{array}$ & $\begin{array}{l}\text { DENTS } \\
\text { Wrong } \\
\text { Answers N } \\
(\%) \\
\end{array}$ & $\begin{array}{l}\text { Total N } \\
(\%)\end{array}$ \\
\hline $\begin{array}{l}\text { Fever is a symptom of } \\
\text { corona virus infection }\end{array}$ & 902 (85.7) & $146(13.8)$ & $\begin{array}{l}1048 \\
(100)\end{array}$ \\
\hline $\begin{array}{c}\text { Dry cough is a symptom } \\
\text { of corona virus } \\
\text { infection }\end{array}$ & $856(81.3)$ & $192(18.3)$ & $\begin{array}{l}1048 \\
(100)\end{array}$ \\
\hline $\begin{array}{l}\text { People that cough with } \\
\text { sputum have corona } \\
\text { virus infection }\end{array}$ & $720(68.4)$ & $328(31.2)$ & $\begin{array}{l}1048 \\
(100)\end{array}$ \\
\hline $\begin{array}{l}\text { Difficulty in breathing } \\
\text { maybe due to corona } \\
\text { virus infection }\end{array}$ & $866(82.3)$ & $182(16.9)$ & $\begin{array}{l}1048 \\
(100)\end{array}$ \\
\hline $\begin{array}{l}\text { Loss of sense of smell } \\
\text { may be due to corona } \\
\text { virus infection }\end{array}$ & $770(73.2)$ & $278(26.4)$ & $\begin{array}{l}1048 \\
(100)\end{array}$ \\
\hline $\begin{array}{l}\text { Someone with corona } \\
\text { virus may not have any } \\
\text { complain at all }\end{array}$ & $620(58.9)$ & $428(41.0)$ & $\begin{array}{l}1048 \\
(100)\end{array}$ \\
\hline $\begin{array}{l}\text { Corona virus is not } \\
\text { curable }\end{array}$ & $640(60.8)$ & $408(38.8)$ & $\begin{array}{l}1048 \\
(100)\end{array}$ \\
\hline $\begin{array}{c}\text { We must wear mask } \\
\text { when we are interacting } \\
\text { with people }\end{array}$ & $864(82.1)$ & $184(17.4)$ & $\begin{array}{l}1048 \\
(100)\end{array}$ \\
\hline $\begin{array}{l}\text { We must ensure at least } \\
2 \text { metres between us and } \\
\text { other people }\end{array}$ & $864(82.1)$ & $184(17.4)$ & $\begin{array}{l}1048 \\
(100)\end{array}$ \\
\hline $\begin{array}{l}\text { We can touch our eyes, } \\
\text { mouth and nose with } \\
\text { unwashed hands }\end{array}$ & $690(65.5)$ & $358(34.0)$ & $\begin{array}{l}1048 \\
(100)\end{array}$ \\
\hline $\begin{array}{l}\text { We should be our hand } \\
\text { with soap or use hand } \\
\text { sanitizer }\end{array}$ & 928 (88.2) & $120(11.4)$ & $\begin{array}{l}1048 \\
(100)\end{array}$ \\
\hline $\begin{array}{c}\text { We should avoid } \\
\text { crowded places and } \\
\text { events }\end{array}$ & $952(90.4)$ & $96(9.1)$ & $\begin{array}{l}1048 \\
(100)\end{array}$ \\
\hline
\end{tabular}

TABLE IV: RELATED BEHAVIOUR OF RESPONDENTS TO COVID-19

\begin{tabular}{ccccc}
\hline Question & A lot & $\begin{array}{c}\text { Some } \\
\text { changes }\end{array}$ & A little & $\begin{array}{c}\text { Not at } \\
\text { all }\end{array}$ \\
\cline { 2 - 5 } & $\mathrm{N}(\%)$ & $\mathrm{N}(\%)$ & $\mathrm{N}(\%)$ & $\mathrm{N}(\%)$ \\
\hline $\begin{array}{c}\text { How much has corona Virus } \\
\text { changed your way of doing } \\
\text { things }\end{array}$ & $\begin{array}{c}852 \\
(80.9)\end{array}$ & $18(1.7)$ & $2(0.2)$ & $\begin{array}{c}176 \\
(16.7)\end{array}$ \\
$\begin{array}{c}\text { How much has coronas virus } \\
\text { changed your daily activity }\end{array}$ & $\begin{array}{c}430 \\
40.9)\end{array}$ & $\begin{array}{c}120 \\
(11.4)\end{array}$ & $254(24.1)$ & $\begin{array}{c}244 \\
(23.2)\end{array}$ \\
$\begin{array}{c}\text { How much has Corona Virus } \\
\text { changed your previous plans }\end{array}$ & $\begin{array}{c}782 \\
(74.3)\end{array}$ & $4(0.4)$ & $61(5.8)$ & $\begin{array}{c}201 \\
(19.1)\end{array}$ \\
\hline
\end{tabular}

TABLE V: RESPONDENTS CONFIDENCE IN PREPAREDNESS FOR COVID 19

\begin{tabular}{|c|c|c|c|c|}
\hline \multicolumn{5}{|c|}{ OUT BREAK } \\
\hline \multirow[t]{2}{*}{ Question } & $\begin{array}{c}\text { Very } \\
\text { confident }\end{array}$ & $\begin{array}{c}\text { Somewhat } \\
\text { confident }\end{array}$ & $\begin{array}{c}\text { Not very } \\
\text { Confiden } \\
\mathrm{t}\end{array}$ & $\begin{array}{c}\text { Not } \\
\text { confiden } \\
\mathrm{t} \text { at all }\end{array}$ \\
\hline & $\mathrm{N}(\%)$ & $\mathrm{N}(\%)$ & $\mathrm{N}(\%)$ & $\mathrm{N}(\%)$ \\
\hline $\begin{array}{l}\text { The federal } \\
\text { government of } \\
\text { Nigeria can prevent } \\
\text { large outbreak of } \\
\text { COVID } 19\end{array}$ & $156(14.8)$ & $194(18.4)$ & $\begin{array}{c}602 \\
(57.2)\end{array}$ & $96(9.1)$ \\
\hline $\begin{array}{c}\text { I am personally } \\
\text { prepared as a person } \\
\text { if there is a large } \\
\text { outbreak of COVID } \\
19 \text { in Nigeria }\end{array}$ & $158(15.0)$ & $198(18.8)$ & $\begin{array}{c}576 \\
(54.7)\end{array}$ & $\begin{array}{c}116 \\
(11.0)\end{array}$ \\
\hline
\end{tabular}

TABLE VI: RESPONDENTS CONFIDENCE IN GOVERNMENT PREPAREDNESS FOR COVID 19 OUT BREAK BY OCCUPATION

\begin{tabular}{ccccc}
\multicolumn{5}{c}{ FOR COVID 19 OUT BREAK BY OCCUPATION } \\
\hline $\begin{array}{c}\text { The federal } \\
\text { government of } \\
\text { Nigeria can }\end{array}$ & $\begin{array}{c}\text { Very } \\
\text { confident }\end{array}$ & $\begin{array}{c}\text { Somewhat } \\
\text { confident }\end{array}$ & $\begin{array}{c}\text { Not very } \\
\text { Confident }\end{array}$ & $\begin{array}{c}\text { Not confident at } \\
\text { all }\end{array}$ \\
$\begin{array}{c}\text { prevent large } \\
\text { outbreak of }\end{array}$ & & & & \\
COVID 19 & & & & \\
Other Occupation & $50(4.8)$ & $33(3.1)$ & $216(20.5)$ & $274(26.0)$ \\
Health Workers & $20(1.9)$ & $18(1.7)$ & $114(10.8)$ & $323(30.7)$ \\
Total (\%) & $70(6.7)$ & $41(3.9)$ & $330(31.4)$ & $597(56.7)$ \\
\hline
\end{tabular}

\section{DISCUSSION}

This study was conducted between July and September 2020 about five months after the first case of COVID-19 was identified in Nigeria (February $27^{\text {th }}, 2020$ ). Following this, the Nigerian centre for Disease Control (NCDC) and the presidential Task Force on VID-19 (PTF) mounted aggressive campaigns to halt the spread of the virus.

A multisectoral national emergency operations centre was activated at level 3 , the highest level of response in the country for the public health emergency. As at $30^{\text {th }}$ of September 2020, Nigeria had a total of 58,848 confirmed cases with a total of 1,112 deaths. Every of the 36 states and Abuja has recorded cases of COVID-19. This study was to assess the level of awareness, level of correct knowledge of transmission and prevention and the related behavior of health care workers and the clients that access services at obstetrics and gynecology clinics in our environment to see whether the multisectoral approach to control the pandemic is yielding the desired result in this area.

The studies revealed that majority of the respondents are aware of COVID-19 disease (91.2\%). It also revealed that $76.2 \%$ believed that the corona virus disease is in Nigeria. This majority belief is necessary for people to key into the prevention plan of government. It is important for people to adopt prevention measures. This finding is similar to that of Olayinka Victor Ojo at where there was $99.1 \%$ awareness ${ }^{15}$

In this study the respondents showed a good knowledge level regarding transmission and prevention of COVID-19 (76.6) with range of $58.9-90.2 \%$ and more than $50 \%$ for all items in the knowledge questionnaire. This is in agreement with the findings of Bao Liang et al (90\%), ShakofehMaleki et al (99\%) and Wafaa Yousif Abdel Wahed et al [1], [4], [5].

Both the health care workers and non-health care workers demonstrate good knowledge of COVID-19 transmission and prevention. 
This study revealed that COVID-19 has affected the behaviour of a significant number of the participants. $80 \%$ of them agreed that the pandemic has changed the way they do things and $40.9 \%$ agreed that the pandemic has changed their daily activities. Their responses indicate a positive attitude to the pandemic believing that it is preventable.

On the other hand, majority of the participants do not have enough confidence in either the national government or themselves as individuals to handle a large-scale outbreak of the COVID-19 pandemic. Majority of both the health workers and the non-health workers are not very confident the national government can successfully handle a large outbreak. This is a sharp deviation from the study of Bao Liang et al, where the respondents had an optimistic view of their national government's ability to handle large scale COVID-19 outbreak ${ }^{1}$

Majority of the respondents are aware of corona virus disease and have good knowledge of its transmission and prevention and are adopting behaviours to control the spread.

The implication of these findings is that clients and services providers in obstetrics and gynecology clinics are conversant with the COVID-19 pandemic and are adopting steps and modifications that prevent the transmission of the virus from person to person.

\section{LIMITATION}

This study was conducted in four (4) clinics out of so many in this environment and the nation in general, so there is need for caution in using the findings for generalization.

\section{CONCLUSION}

Despite observable knowledge gap in some respondents that needs further education, clients and health care workers in obstetrics and gynecology clinics in this study demonstrated high level of awareness, knowledge and acceptable positive behavior towards the COVID-19 pandemic necessary to guarantee service modifications to prevent person to person transmission.

\section{REFERENCES}

[1] Bao-Liang Zhong, Wei Luo, Hai-Mel, Qian-Qian Zhang, Xiao-Ge Liu, Wen-Tian Li, Yi Li Knowledge, Altitudes and Practices towards COVID-19 among Chinese residents during the rapid rise period of the COVID-19 outbreak. A quick outline cross-sectional survey. International Journal of Biological Sciences2020; 16(10): 1745-1752. doi: $10.7150 /$ ijbs.45221.

[2] The Novel Coronavirus Pneumonia. Emergency Response Epidemiology Team. The epidemiological characteristics of an outbreak of 2019 novel coronavirus disease (COVID-19) in China. China Epidemiology 2020; 41:145-51.

[3] Chen N, Zhou M, Dong X, Qu J, Gong F, Han Y, et al: Epidemiology and Clinical characteristics of 99 cases of 2019 novel coronavirus pneumonia in Wuhan, China: A Descriptive Study. Lancet 2020; 395: 507-13.

[4] ShokefehMaleki, Farid Najafi, Khosro Farhadi, Mahmoud Fakhri,Fatemeh Hosseini, Mehdi Naderi: Knowledge, Altitude and Behavior of Health Care Worker in the prevention of COVID-19. Research Square. Doi: https:/doi.org/10.21203/rs.3 rs-23113/v1.

[5] WafaaYouosif Abdel Wahed, EnasMomdouhHefzy, Mona Ibrahim Ahmed, Nashwa Sayed Hamed. Assessment of knowledge, altitudes and perception of Health care workers regarding COVID-19, A crosssectional study from Egypt. [Pubmed central].

[6] Bogoch II, Watts A, Thomas-Bachli, Huber C, Kraemeh Mug, Khan K.
Potential for global spread of novel coronavirus from China. J. travel Med. 2020; 27 (2) http://dx.doi.org/10.1093/jtm/taaa 011.

[7] Chang, Hx H, Rebazu A, Sharma L, Delacruz CS: Protecting Health Care Workers from subclinical coronavarus infection. Lancet Respir Med. 2020; 8 (3): e13. http://dx.doi.org/10.1016/S22132600(20)30066-7.

[8] Chan JF, Yuaus, Kok KH, To KH, Chu H, Yaug J et al. A familial cluster of pneumonia associated with the 2019 novel coronavirus indicating person-to-person transmission: a study of a family cluster. Lancet. 2020; 395(10223): 514-523. http:/dx.doi.org/10.1016/S02406736(20)30154-9.

[9] Alsahafi AJ1, Cheng AC: Knowledge, attitudes and behaviors of health workers in the Kingdom of Saudi Arabia to MERS coronavirus and other emerging infectious diseases. Int $\mathbf{J}$ environ res public health. 2016; 13(12): 1214. http//dx.doi.org/10.3390/ijerph 13121214.

[10] World Health Organization. Naming the coronavirus disease (COVID19) and the virus that caused it. https://www.who.int/emergencies/diseases/novel-cononavirus2019/technical-guidance/naming-the-coronavirus-disease-(covid-19)and-the-virus-that-caues-it.

[11] WUA et al. Novel Corona Virus (2019-nCOV) Pneumonia in Medical Institutions. Problems in Prevention and Control. Chin J Infect control, 2020.19 pg 1-6.

[12] Ran L, Chen X, Wang Y, Wu W, Zhang L, Tan X. Risk factors of Health Workers with corona virus disease 2019. Retrospective cohort study in designated hospitals of Wuhan in China. Clin infect DIS. 2020. http://dx.doi.org/10.1093/Cid/Ciaa 287

[13] Wang J, Zhou m, Liu F. Reasons for Health Care Workers becoming infected with novel coronavirus disease 2019 (COVID-19) in China. J Hosp Infect. 2020 http://dx.doi.org/10.1016/J.Jhin.2020.03.002.

[14] World Health Organization. Coronavirus disease 2019 (COVID-19). Situation report-152.

[15] Olayinka Victor Ojo, Ramsey MshelizuYalma, Ebenezer Obi Daniel, Paul Olaiya Abiodun, Ahmed Mamudu Bello, IsrealOlukayod Popoola, Christie Omolola Adams. Knowledge, Attitude and willingness of Health care workers towards COVID-19 preventive measures in a tertiary Health Institution in North Eastern part of Nigeria. Central African Journal of Public Health Vol. 6, no5, 2020 PP.251-255.

[16] Heyman DL, Shindo N, COVID-19: What is next for Public Health? The lancet 2020; 395 (10224): 542-543 doi 10.10161501406736(20)30374-3.

[17] Nigeria Centre for Disease Control (NCDC) COVID-19 Report on $29^{\text {th }}$ September, 2020. www.ncdc.gov.org.

[18] Adebagbo, Wonderful Banabasans and Bass, Joshua Samuel: Nigeria's COVID-19 Chronicles. www.Blog.epidalest.org/Nigeria's-COVID-19 chronicles/.

[19] Akogu SPO: COVID-19 and Maternity Services in: The Skilled Birth Attendant. How to give better maternal and new born care pg 146-153. Melchizadek Publishers. 